\title{
DE HERZIENING DER BANKWET IN DE VEREENIGDE STATEN.
}

Het is bekend dat het vraagstuk der regeling van de geldcirculatie in de Vereenigde Staten, reeds sedert een anital jareu aldaar aan de orde van den dag is.

Een tijdlang meenden veleu, dat de vorzaak der uadeeleu van den bestaanden stand van zaken, welke zich telkeus en telkeus weder openbaardeu, gezocht moest wordeu, eenvoudig in gebrek aan voldoende ruilmiddelen ter voorziening in de groote behoefte daaraan bij de voortdurend zoo belangrijke ontwikkeling vau landbouw, nijverheid en handel; en deze meening heeft niet weiuig bijgedragen om te doen besluiten tot de bekende zilveraanmuntingen en aankoopen van zilver tegèn uitgifte van zilvercertificaten. Door deze is echter de hoeveelheid ruilmiddelen inderdaad wel toegenomen - tevens intusschen de samenstelling van de totaalsom van metalen ruilmiddel zeer bedorven zijude maar gunstige gevolgen hebben die maatregelen geen enkele gehad. Het is later toch gebleken dat, voorzooveel er werkelijk behoefte bestond aan vermeerdering van het metalen ruilmiddel, daaraan gemakkelijk voldaan kon worden door opneming van meer goud in de circulatie. Feitelijk is in de latere jaren de totaalsom der circulatie en inzonderheid ook die van gouden munt en muntmateriaal zelfs zoo aanmerkelijk vermeerderd, dat indien men den geldomloop der Vereenigde Staten vergelijkt met die van andere landen, men niet begrijpt hoe aldaar over onvoldnendheid van het ruilmiddel geklaagd kon worden.

Toch werd het steeds duidelijker dat wel degelijk er iets aan aan den toestand haperde. En wel werd deze overtuiging herhaaldelijk aangewakkerd door hen die niet wisten te ouderscheiden tusschen eigenlijke geldschaarschte eu kapitaalbehoefte, dus op onjuiste gronden; maar ook zij die beter inzicht in den stand 
van zaken hadden, moesten meer en meer erkeunen dat, andere oorzaken daargelaten, de telkeus terugkeerende spanuing ter geldmarkt voor een niet gering deel haar oorzaak vond in gebrekkige organisatie van het circulatiewezen.

Ook begon men zich beter rekenschap te geven van wat het was dat daaraan eigenlijk haperde, dit hoofdzakelijk zijnde het volkomen gebrek aan elasticiteit der bankbiljetten-circulatie.

Maar werden aldus èn het eigenlijke $k$ waad èn de juiste oorzaak daarvan meer en meer erkend, toch is tot heden toe niets gedaan ter verbetering vau den toestand. ${ }^{r}$ ergeefs werd daarop bij herhaling angedrongen zoowel in de jaarlijksche Boodschap van den President als in de jaarverslagen van den Secretary of the Treasury en van den Comptroller of the Currency; werden ook zelfs wetsontwerpen ter voorziening in deu toestand bij het Congres ingebracht, o. a. reeds in 1896 het bekende voorstel Fowler; terwijl tevens het onderwerp in tal van geschriften en in allerlei bijeenkomsten telkens en telkens weder behandeld werd; het bleef daarbij en tot handelen kwam men niet.

Eindelijk echter in de allerlaatste maanden is hieriu veranlering gekomen. De buiteugewoon heftige spanuing welke in deu vorigen winter aan de geldmarkt te New York heeft geheerscht, terwijl toch landbouw, nijverheid en handel over het geheele land van grooten voorspoed blijk gaven, heeft de oogen geopend voor de noodzakelijkheid van eenige handeling.

Inzonderheid heeft hiertoe medegewerkt eene redevoering vau den bekenden bankier J. H. Schiff, den $5^{\text {den }}$ Januari l.l. gehouden in de vergadering van de Kamer van Koophandel van den strat New York. Met nadruk gaf de spreker als zijne meening te kennen, dat handhaving van den bestaanden toestand te eeniger tijd zou leiden tot een crisis zoo ernstig als nog nooit beleefd was, en dat dit gevar slechts uit den weg te ruimeu was door overgang tot eene elastieke bankbiljetten-circulatie.

Naar aanleiding dezer redevoering belastte de Kamer toen eene commissie uit haar midden met het opstellen van een rapport over hetgeen te doen zou zijn in de richting, door den heer Schiff aangegeven. Reeds in de vergadering der Kamer vau 1 Februari werd dit rapport uitgebracht. Het bleek echter daaruit, dat de commissie niet diep op het vraagstuk was ingegaau en hare leden het niet aandurfdeu doortastende maatregeleu aau te bevelen. 
De heer Schiff stelde daarom voor, in annsluiting asu zijne vorige redevoering, dat de Voorzitter der Kamer vijf harer leden zou aan wijzen tot een nader ouderzoek van het geheele vraagstuk der regeling van het circulatiewezen, welke commissie ook het recht zou hebben zich andere leden buiten de Kamer te assumeeren of met andere personen in overleg te treden, en vall welke commissie, eventueel, verwacht zou wordeu een voorstel tot herziening der bankwet, dat aan den Secretary of the Treasury zou kunneu wurdeu aaubevolen ter overbrenging aau den President.

In Maart kwam deze Commissie tot strnd, samengesteld zijnde uit de heeren:

John Claflin, de bekende koopman, voorzitter der commissie;

Frank A. Vanderlip, President van de National City Bank;

Isidor Straus, koopman en bestuurslid van verschillende financieele iustellingen;

Dumont Clarke, President van de American Exchange National Bank; en

Charles A. Conant, Treasurer van de Morton Trust $C^{o}$. en algemeen bekend door ziju geschriften over financieele onderwerpen;

met Joseph French Johnson als secretaris.

Aanstonds aanvaardde de commissie hare taak en, gelijk uit haar rapport is gebleken, ving zij hare werkzaamheden aan door schriftelijk en mondeliug raadplegen met een aantal mannen van zaken en andere autoriteiten in de verschillende deelen der Vereenigde Staten, alsmede met bestuurders van de voornaamste circulatiebanken in Europa. De vrucht van haar arbeid is een uitvoerig rapport, dat den $4^{\text {den }}$ October l.l. aan de Kamer van Koophandel voorgelegd, door deze werd goedgekeurd.

Het rapport werd ook algemeen verspreid en inzouderheid aan het oordeel onderworpen van de Banker's Convention, welke jaarlijks bijeenkomt en dit jaar van 16 tot 19 October te St. Louis vergaderde. Door deze vereeniging werd het na eenige discussie in handen gesteld eener speciale commissie van vijftien harer leden, aan welke werd opgedragen zich in verbinding te stellen met de ontwerpers, ten einde met deze, alsmede zoo mogelijk met de currency-commissies van het Huis van Vertegenwoordigers en van den Senaat, zich te verstaan omtrent een voordracht ter wijziging der baukwet in de richting als door het rapport aangegeven. 
Volgens de jongste berichten heeft dit overleg alreeds tot een afdoend resultant geleid en is nu dientengevolge in de aanstaande zitting vau het Congres een wetsvoorstel te wachten.

Alvorens in bijzonderheden te treden betreffende dit wetsvoorstel, zal het nuttig zijn vian het rapport zelf - het Currencyreport by the special Committee of the Chamber of Commerce of the State of New York - een résumé te geven, omdat het eene volledige uiteenzetting van het vraagstuk bevat, met vermelding van al de moeilijkheden aan de oplossing daarvan verbonden.

De Commissie begint met te constateeren welke de totaalsom was der circulatiemiddelen op 1 Juli l.l.

Gouden munt eu m. m. . . . . D. 1.475.841.821

Biljetten der Vereenigde Staten . . "346.681.016

Schatkistbiljetten 1890 . . . . . " 7.386 .000

Zilveren standaard dollars of certificaten " 560.864 .855

Biljetten der Natiouale banken. . . " 561.112 .360

Zilveren pasmunt . . . . . . . " 117.998 .588

Totaalsom . . . D. 3.069.884.640

waarvan in werkelijke circulatie was D. 2.744.483.830 en in de schatkist berustte D. $325.400 .810 .{ }^{1}$ )

De teekenmunt en het fiduciaire ruilmiddel, voegt de commissie aau deze opgave toe, worden op de goudwaarde gehandhaafd door hunne inwisselbaarheid of door beperking van bet bedrag, en, in aanmerking genomeu de bepalingeu der wet van 14. Maart 1900 , acht zij het niet noodig dat voorshauds te dezen opzichte nieuwe maatregelen worden genomen.

1) Op 1 Nov. l.l. waren deze bedragen als volgt:

Gouden munt en m. m. . . . . . . . D. 1.566.619.131

Biljetten der Vereenigde Staten . . . . " 346.681 .016

Schatkistbiljetten 1890 . . . . . . . . " 6.912 .000

Zilveren standaard dollars of certificaten. " 561.339 .530

Biljetten der Nationale banken'. . . . . " 583.171 .985

Zilveren pasmunt. . . . . . . . . . " 123.785 .299

Totaalsom . . D. 3.188.508.961

waarvan in werkelijke circulatie . . . . " 2.866 .882 .786

en in de schatkist berustte . . . . . . " 321.626 .175

De werkelijke circulatie hedroeg aldus D. 33.68 per hoofd der bevolking (geschat op 1 Nov. 1.l. te bedragen 85.131 .000 zielen). 
Maar, gaat zij voort, de circulatie gaat mank aan dit groote euvel dat ze een vaste grootheid uitmaakt, aan uitzetting noch inkrimping onderhevig, en hieruit ontstant voor de handelsbelangen een aanzienlijk nadeel. Het euvel wordt veroorzaakt door de wetsbepalingen welke - geheel onnoodig - de banken beperken in de uitgifte van het kredietpapier dat dienst doet als ruilmiddel, het baukbiljet.

Omstandig wordt de loop van zaken dan in het verslag beschreven. Bijkans de helft der bevolking van de V. S. is werkzaam in het landbouwbedrijf en al de oogsten rijpen in het najnar. Dit veroorzaakt op tweeërlei wijze buitengewone behoefte aan tijdelijke beschikking over kapitaal. De eene behoefte is die der koopers en verschepers van de landbouwproducten; aan hun vraag kunnen de bankeu voldoen door de opening van boekkredieten, waaruit slechts voortvloeit vermeerdering van voorschotten en van deposito's. Mar een andere is de vrag van de landbouwers en planters, die hun arbeiders moeten betalen met algemeen gangbare betralmiddelen. Hier baat dus geen uitzetting der gewone kredietbeweging; aan die aanvragen moeten de banken voldoen door zich te ontdoen van de wettige betaalmiddelen welke hare reserves vormen. Het gevolg is de vermindering der bankreserves juist op het tijdstip dat de kredietvrang levendig is. Welke de juiste omvang is van deze tijdelijke buitengewone behoefte aan betaalmiddelen, trouwens uit den aard der zaak het eene jaar grooter dan het andere, is niet bekeud. Maar zooveel is zeker, dat de plaatselijke binnenlandsche banken daarann niet uit eigen beschikbare middelen voldoen kumen, en dus die vraag voor een deel moeteu overbrengeu naar de banken in de reserve-steden en ten slotte in hoofdzaak naar Chicngo en New York. Het wordt waasrchijnlijk geacht, dat het bedrag aan algemeen gangbare betaalmiddelen, dat op die wijze in het najaar door de groote stedelijke banken naar het binnenlaud te verzenden is, allicht 150 millioeu dollars bedraagt. In 1905 werd alleen door bemiddeling van zes der vooruaamste banken van Chicago 92 milliven dollars uitbetaald. Die betaalmiddelen nu, hierop moet wel gelet worden, zijn die waaruit de reserves der banken bestaan. En daar de obligos der banken voor ten minste 25 pct. door hare reserves gedekt moeten ziju, beteekent dus een out- 
trekking van 100 millioen aan die reserves eene vermindering van 400 millioen van harr maximum operatie-vermogen, van het maximum waarop zij haar opereerend kapitaal kunnen opvoeren. Het onvermijdelijk gevolg der oogst-bewegiug is dientengevolge altijd een groote spanning aan de geldmarkt, met al de gewone uitwerkingen van deze.

Maar dit is nog niet eens het eenige nadeelige gevolg der gebrekkige regeliug van het kredietwezen. Op de buitengewoon levendige geldvraag vau het najaar voor het binnenlaud, volgt geregeld in den loop van den winter en in het voorjaar eveu sterke terugstrooming van betaalmiddeleu uit het binneuland naar de steden. Eu daar de stedelijke banken over de haar verstrekte depositos rente vergoeden, zijn zij niet bereid alsdan de haar alzoo toestroomende middelen ongebruikt te laten. Op de rentekoersen wordt hierdoor natuurlijk grooten druk uitgeoefeud, en daar de banken wel zorgen die middelen, welke haar slechts voor beperkten tijd toevloeien, niet op lange termijnen uit te leenen, zijn het vooral de call-loans waarmee zij vrijgevig zijn, zich daarvoor zelfs met zeer lage reute te vreden stellende, waaruit weder voortvloeit bevordering der speculatie, inzonderheid ann de fondsenmarkt. De bekende "spring-boom" wordt alzoo volkomen verklaard. Deze is de natuurlijke uitwerking van tijdelijke overvoering der geldmarkt met betaalmiddelen, gelijk de najaars spauning het gevolg is der zich alsdan opeubarende buitengewone. vraag daarnaar.

Deze loop van zaken nu, worlt geacht de uitkomst te ziju der bestaande bankwet. Wel veroorlooft deze aan de Nationale bauken de uitzetting harer boekkredieteu, maar niet die harer biljettencirculatie. Toch is er - wordt terecht in het verslag gezegd geen essentieel verschil tusschen kredietverleening in den vorm van een boekkrediet en in dien van biljetten-uitgifte. Doch door de tweeërlei vorm van krediet verleening kau niet in dezelfde behoeften voorzien worden. Door de opeuing vau boekkredieten en het cheque-verkeer, dat daaruit ontstant, wordt uitsluitend plaatselijk in de behoefte nau betaalmiddelen voorzieu, terwijl voor het zich over het geheele land uitstrekkeude verkeer en bepaaldelijk voor het verkeer in die kringen waar men geeu bank-rekeuing houdt, slechts de circulatie van bankbiljetten het gebruik der wettige betaalmiddelen kau vervangen. "Indien 
- zegt de Commissie in haar verslag - het aan de banken veroorloofd ware in het seizoen der oogstbeweging hare uitgifte van bankbiljetten met 100 aे 200 millioen dollars te vermeerderen, zouden deze biljetten alsclan over het land verspreid wordeu eu aldaar de dieusteu bewijzen waarvoor nu wettige betaalmiddelen gevorderd worden. En terwijl : :lsdau de bankeu niet meer verplicht zouden zijn deze betaalmiddelen af te geven uit die welke hare reserves vormen, zouden zij niet, zooals thans het geval is, tot inkrimping harer kredieten genoodzaakt worden"; zegge, tot vermindering harer kredieten in de verhouding als veroorzaakt wordt door het wegvloeien harer reserves.

Onder de bepalingen der wet, welke tegenwoordig de uitgifte van bankbiljetten regelt, kunnen deze echter niet dienen ter voorziening in de behoefte aan betaalmiddelen welke uit de oogstbeweging ontstaat. Bankbiljetten kunnen slechts uitgegeven worden tegen depôt van staatsobligatien. Eene bauk, hare biljetten-circulatie wenschende te vermeerderen, moet beginnen met voor gelijk bedrag staatsobligatiën te koopeu. De ervaring van veertig jaren heeft geleerd, dat door baukbiljetten, op dergelijkeu grondslag uitgegeven, niet in tijdelijke behoeften aan betaalmiddelen voorzien kan worden.

Het verslag treedt dan in eene nadere behandeling van het karakter vau het baukbiljet der Vereenigde Staten en van de algeheele samenstelling der circulatie aldaar. En wijl hier eigenlijk de sleutel ligt van de moeilijkheden warmede men te kampeu heeft, zal het 't best zijn deze paragraaf in haar geheel over te nemen.

Het is geweuscht - zegt de commissie - om de aandacht te vestigen op een belnugrijk onderscheid tusschen het bankbiljet en alle andere soorteu van betaalmiddelen. De zilveren dollar, het zilver-certificaat, de schatkistbiljetteu en de statsbiljetten ontleenen aan de wet eeue hoedanigheid welke het bankbiljet niet bezit en niet moet bezitten, te weten van te zijn wettig betaalmiddel, zoodat zij in de reserves der banken meetellen zoo goed als het goud zelf. Iedere vermeerdering in de hoeveelheid van deze geldsoorten zou, dientengevolge, onvermijdelijk leideu tot verhooging vau de macht der bankeu tot uitzetting harer krediet-verleeningen, want noodzakelijkerwijs zou eeu deel zijn weg vinden naar de bank-reserves. Eeu bank- 
biljet echter kan, tenzij in de staats- of particuliere kassen, niet als geld geteld worden. In de kas eener Nationale bank is het niets anders dan een belofte tot betaling, welke vog in handen is van den afgever - een ongebruikt kredietmiddel, dat nog geen verbintenis der bauk uitmaakt en zonder invloed is op de prijzen van goederen of fondsen. Bankbiljetteu ziju geen geld en aan hen moeten door de wet niet de rechten, aan het geld verbonden, gegeven worden. Zij ziju slechts bestemd om als betaalmiddel diensl te doen, en de voorwaarden aan de uitgifte verbonden, moeten, evenals het geval is ten aanzien der uitgifte van cheques, zoodanig ziju, dat ze slechts in het leven worden geroepen wauneer daaraan behoefte bestaat en dat ze ingewisseld of teruggetrokken worden wanneer ze hun werk verricht hebben. Intusschen, daar het bankbiljet zeker gesteld is door het depot van staatsobligatiën, schijut het even goed "geld" te zijn als de staatsbiljetten. Waarom dan, wordt dikwijls gevraagd, wordt het niet als geld beschouwd en als zoodanig opgenomen in de bank-reserves? De ervaring heeft echter geleerd, dat dit hoogst gevaarlijk zou zijn. Het baukbiljet, onverschillig welke de bijkomende waarborgen zijn, is een obligo van eeu bank, juist zooals een "certified check" (een door een bank goedgekeurde cheque) dit is, en kau ieder oogenblik ziju uitbetaling in werkelijk geld noodig maken. Het bankbiljet tot wettig betaalmiddel te maken, zou gelijk staan met aan de banken te vergunuen de bedragen, haar door andere banken verschuldigd, ouder hare reserves op te nemen. Indieu zoo iets werd toegestaan door de wet, zou er geeu grens wezen aan de nitzetting der bankobligo's en kredietverleeningeu zonder eenige vermeerdering vau reserve in werkelijk geld. Indien bank A de biljetten ran bank B als wettig betaalmiddel kon beschouwen, en bank B hetzelfde kon doen met de biljetten vau bauk $A$, zou de uitkomst dezelfde zijn alsof de bankeu hare eigeu biljetten als reserve koudeu aannemen. Dit zou feitelijk leiden tot de conversie vau de geheele gecousolideerde Staatsschuld in biljetten inwisselbaar op vertoon, gelijk aan de bestaande staatsbiljetten, ell het zou niet minder gevaarlijk ziju omdat het slechts een indirecte en gemaskeerde conversie ware, want op die wijze zou de vermeerdering in het bedrag all uitstaande baukbiljetten leiden tot het uitstooteu van het goud en dus 
de handhaving van den gouden staudaard in gevaar brengen, even zeker als dit geschieden zou door een vermeerdering van de staatsbiljetten zelveu.

Dit betoog gehouden hebbende -- een betoog, gelijk men bemerkt zal hebben, dat uitsluitend betreft de toestanden in de Vereenigde Staten, en niet een theoretisch betoog is over het karakter van bankbiljetıen in het algemeen - zegt de commissie dat, trots de bestaande moeilijkheden, het vraagstuk van de regeling der circulatie toch op verschillende wijzen ware op te lossen. Maar er is eene zaak, waarmede rekening moet worden gehouden en wardoor men beperkt wordt in de keuze der middelen.

Dit is het feit, dat de Nationale banken houders rijn van een bedrag vau ruim 600 millioen dollars staatsobligatien, terwijl de marktwarde dezer obligatien in ruime mate bepaald wordt doordat ze tot onderpaud dienen van de bestannde bankbiljetten. Hierin kan geen verandering gebracht worden. Wilde men dit wel doen, eene belangrijke prijsdaling der staatsobligatien zou niet uitblijven. Dit ware op zich zelf niet gewenscht: daargelaten dat het vooruitzicht iedere belanghebbende bij de Nationale banken in het harnas zou jagen tegen zulk een wijziging vau den bestannden toestand.

Het beste middel om het vraagstuk op te losseu, zou volgeus de commissie bestaan hebben in de oprichting eeuer Centrale Circulatiebank narst de bestaande Nationale banken, doch uitsluitend optredende als bauker's bank, zegge alleen het papicr van andere banken in disconto nemende. Deze bank had overigens geschoeid moeten worden op de leest der groote Europeesche, circulatiebanken, hare biljetten in werkelijkheid een kredietpapier zijnde warvau het bedrag zou afwisselen naar gelang der behoeften van het verkeer. Voorts had deze bank belast moeten worden met de waarneming van het knssierschap van de federale regeering, en hierdoor een einde gemaakt zijn aan de tegenwoordige organisatie der Schatkist.

Wij behoeven hier echter op het voorstel tot oprichting eenter dergelijke centrale bankinstelliug niet verder in te gaan. Geen oogenblik is er sprake van geweest, dat het daartoe kon komen. Het vooroordeel tegen de vernieuwde vestiging eener Bank der Vereenighle Staten is, door de herinnering an de twee 
vroegere proefuemingen in deze richting, nog onoverkomelijk. De staatkundige verhoudingen zouden voorts de uitvoering van zulk een plan onmogelijk hebben gemaakt.

Trouwens de Commissie blijkt zelve dit van den aanvang af begrepen te hebben. Dadelijk heeft zij een auder voorstel gedaan, naast dat tot oprichting eener centrale circulatiebank; voor het geval dat daartegen politieke of financieele bezwaren zoudeu bestaan. Het heeft alle schijn alsof zij het eerste voorstel eigenlijk alleen gedaan heeft pour acquit de consoience, omdat zij theoretisch dit het beste achtte. Immers tesr aauzien van het tweede voorstel treedt zij in veel meerdere ontwikkeling harer deukbeelden dan ten opzichte ran het oorspronkelijke plan.

Dit tweede vourstel nu is in hoofdzaak, dat aan de Nationale banken het recht zal worden verleend tot eene verdere uitgifte vau bankbiljetten dan de bestanude. Maar hierbij - uitdrukkelijk wordt daarop geiusisteerd - moet er wel op gelet worden, dat het geen blijvende ritzetting val fidudiaire betaalmiddelen is welke verlaugd wordt. dat integendee] een zoodauige zeer gevaarlijk zou geacht worden, omdat die allicht een uitstruorning van goud zou verooraken, waardoor het vertrouwen in de handhaving van deu gouden standaard geschokt kou worden. Vereischt wordt - zegt de Commissie - eene vermeerdering van betaalmiddelen die niet vau blijvenden aard rij, een nieuwe betalmiddel warvan de uitgifte en intrekking zich regelf, naar de wisselende behoeften daaranu.

De uitgifte der nieuwe biljetten moet daarom gehecl losgemaakt worden vau belegging in staatsobligatiëu, een verband waaran de circulatie der bestande bankbiljetten har permament karakter outleent. Zelfs zou niet het bedrag der nieuwe biljetten, tot uitgifte waarvan de banken gerechtigd zouden vaste verhouding moeten siaan tot dat harer tregen depôt van staatsobligatiën uitgegeven biljetten.

Wel acht de Commissie het noodzakelijk, dat aal het recht tot uitgifte der nieuwe bankbiljetten, der eigeulijke kredietbiljetten, verboudeu zij le verplichtiug tot belegging van een deel van het kapitaal der bank in staatsobligatien. Geschiedde dit niet, zoo zouden de bankeu hare bestaande biljetten-circulatie in zoodanige mate door dic der nieuwe biljetten kunnen vervangen, dat danruit anmzienlijke verkoupen der stantsobligatien

Econ. 1906. 
voortsproten. en dit, als reeds gezegd, moet voorkomen worden. De door staatsobligatien gewaarborgde biljetten-circulatie der Nationale banken bedraagt thans ongeveer $60 \mathrm{pCt}$. van haar gezamenlijk kapitaal; bij eenige is het veel meer dan 50 pCt., bij andere echter niet meer dan het door de wet vereischte minimum, d.i. $25 \mathrm{pCt}$. De commissie zou $n u$, als voorwaarde om tot de uitgifte van de nieuwe biljetten gerechtigd te zijn, een minimum van 50 pCt. willen vast stellen voor de bedoelde verhouding. Mogen al enkele banken alsdan tot verkoop vau staatsobligatien komen, andere zullen daartegenover staan om die te koopen ten einde mede gerechtigd te worden tot het uitgeven der nieuwe biljetten.

Maar tot welk bedrag zoude het dan aan de Nationale banken veroorloofd moeten worden de nieuwe biljetten uit te geven? Dienaangaande stelde de Commissie het volgende voor. Ten eerste, te handhaven de bestanude bepaling, volgens welke iedere bank gerechtigd is tot de uitgifte van door staatsobligatiëu gewaarborgde biljetten tot het volle bedrag van haar kapitaal, en hieraan toe te voegeu, dat iedere bank vrij zou blijven al of niet tot de uitgifte der nieuwe biljetten over te gaan, en, dit niet doende, ook geen andere verplichtingen zou hebbeu dan die welke uit de bestaaude wet voortspruiten. Voorts, dat het bedrag der uit te geven krediet-biljetten voor iedere bank zou moeten staan in eene bepaalde verhouding tot haar kapitaal, deze verhouding op $35 \mathrm{pCt}$. gesteld wordende. Aannemende dat anu het nieuwe betaalmiddel behoefte zou bestaan tot een bedrag van 150 millioen dollars, zoù een uitgifte in de verhouding van 25 pCt. van het kapitaal der banken voldoende te achten zijn geweest; maar omdat sommige banken mogelijk zich onthouden zouden aan de uitgifte gevolg te geven, en andere, die aldus konden handelen, wel van hun recht gebruik zouden maken doch daarentegen een zeker bedrag aan oude biljetten zouden intrekken, werd de vaststelling op een eenigszins hooger perceutage wenschelijk geacht.

Verder achtte de Commissie enkele speciale bepalingen noodig om tegen te garn, dat de uitgifte der kredietbil:etten zou leiden tot overmatige uitzetting der circulatie in haar geheel. In de eerste plaats zou daartoe vereischt worden, dat over het geheele land heen talrijke gelegenheden geopend wierden ter inwisseling 
van alle biljetten. Voorkomen moest worden dat eenige bank, hiertoe genoopt door een te verren afstand van het kantoor van inwisseling, biljetten van andere bankeu bij haar ingekomen, zou bezigen voor haar eigen betalingen. De commissie voegt hieraan toe, dat zij snelle inwisseling van bankbiljetten zoozeer gewenscht acht, dat zij wel een wettelijk verbod voor de banken, om met de biljetten vau andere banken betalingen te doen, had willen voorstellen, indien dergelijke wettelijke regeling uitvoerbaar ware; maar dit het geval uiet zijude, moest al het mogelijke gedaan worden ter bevordering van snelle en gemakkelijke inwisseling.

In de tweede plaats en dit als direct middel ter beperking van de circulatie der krediet-biljetten, stelde de commissie voor, eenigszius in navolging van de Duitsche bankwet, om deze biljetten te onderwerpen aan eene speciale belasting, en die belasting progressief te maken naarmate het bedrag der uitgifte zou stijgen. Zij gaf daarbij de volgende schaal aan de hand.

Bij een maximum uitgifte, als voorgesteld, van 35 pCt. van het bankkapitaal:

\begin{tabular}{|c|c|c|c|c|c|c|c|c|}
\hline \multicolumn{9}{|c|}{ belasting 2 pCt. } \\
\hline & $"$ & " & tweede & 5 & " & " & 3 & " \\
\hline & $"$ & " & derde & 5 & $"$ & $"$ & 4 & 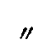 \\
\hline & $" 1$ & " & verdere & 10 & $"$ & " & 5 & \\
\hline eindelijk & $\mathrm{x} "$ & $"$ & laatste & 10 & " & $"$ & 6 & \\
\hline
\end{tabular}

Volgeus de bijgevoegde berekening zou naar dien maatstaf, bij de bestaande totralsom van bankkapitaal ad D. 826.000.000 (per 18 Juni 1906), de circulatie der krediet-biljetten kunnen stijgen tot

D. 41.300 .000 tegen 2 pCt. belasting.

$\begin{array}{llllll}\text { " } 41.300 .000 & 3 & 3 & \text { " } & \\ \text { " } & 41.300 .000 & \prime & 4 & \text { " } & \text { " } \\ \text { " } & 82.600 .000 & \text { " } & 5 & \text { " } & \text { " } \\ \text { " } & 82.600 .000 & \text { " } & 6 & \text { " }\end{array}$

tezamen D. 289.100 .000 als maximum.

De Commissie maakt daarbij de opmerking, dat bij eene belasting tot $4 \mathrm{pCt}$. toe het maximum der uitgifte niet meer dan D. 123.900 .000 zou bedragen, terwijl de belasting van 5 en $6 \mathrm{pCt}$. alleen bij buitengewoon hoogen rentestand zou kunnen 
worden opgebracht. Zij vestigt, verder er de aandacht op dat reeds de wetenschap, dat des noodig tot deze uiłgifte van additioneele betaalmiddelen zou kunnen worden overgegaan, menigmaal een gunstigen iuvloed zou hebben op de geldmarkt; immers daardoor zou vermeden worden de bezorgdheid welke bij den bestaanden stand van zaken zich herhaaldelijk openbaarde, wat, bij gebrek aan dergelijke buitengewone uitzetting van kredietmiddelen, op een gegeveu oogenblik moest gebeuren, eene bezorgdheid die alsdan telkens aanleiding gaf tot onnoodige vermeerdering der bestaande spanning. Maar zou het voorgestelde middel ter voorziening in de behoeften der geldmarkt aan het doel beantwoorden, dan zou, eventueel, het dadelijk in toepassing gebracht moeten kumen worden. De zaak zou dus zoo geregeld moeten wordeu, dat de kredietbiljetten steeds gereed waren om desverlangd anu de bauken ter haud gesteld te worden.

Het bedrag der belasting zou in handeu der regeering een garantiefonds moeteu vormen om, bleek zulks noodig te zijn, bij te dragen tot inwisseliug der biljetteu, uitgegeven door eene bank welke in gebreke zou blijven. De commissie berekende dat dit fonds spoedig aan de regeering voldoende middelen zou verschaffeu ter bestrijding van eventueele verliezen. Geeuszins zouden de biljetten een gepriviligeerde vordering tegenover de bauken moeteu uitmaken. Een voorrang welke, gelijk elders is opgemerkt, eeu nadeeligen iuvloed zou uitoefenen op de verhouding der banken tegenover hare deposito-gevers. De regeering, merkte de Commissie hierbij op, heeft met het oog op hare verplichting, om de bankbiljetten steeds in betaling aantenemen, dien voorrang ook niet noodig dewijl zij, door het toezicht dat zij over de banken houdt, voldoende macht in handen heeft om zich voor verliezen te vrijwaren.

Uitdrukkelijk werd verder opgemerkt, dat het in de bedoeling lag der Commissie om de nieuwe baukbiljetten, de kredietbiljetten, wat den vorm, het uiterlijk voorkomen betreft, geheel gelijk te stellen met de bestaande bankbiljetten, gelijk ook alle verplichtingen der regeering ten opzichte van het in betaling nemen der bankbiljetten evenzeer op de kredietbiljetten van toepassing zouden zijn. Conform de bestannde bepalingen zou de schatkist verplicht zijn al de biljetten eener bank, welke hare betalingen zou staken, op vertoon in te wisselen, 
de middelen har hiertoe verstrekt wordende door het garantiefonds vau 5 pCt. dat de banken deponeeren over alle door haar uitgegeven biljetten, voorts door het fonds uit de belastingheffing ontstaande. Voor de aldus te verrichten voorschotten, voorzooveel niet gedekt door de staatsobligatiën door dergelijke bank gedeponeerd, inbegrepen hunne meerwaarde boven de daartegen uitgegeven biljetten, en door andere activa der bank ouder haar berusting, zou de schatkist slechts eene concurrente vordering op de bank hebben, maar deze zou toch altijd blijven beneden het totale bedrag der kredietbiljetten.

Voorts wees de Commissie op de noodzakelijkheid om, werd ann haar voorstel uitvoering gegeven, tevens over te gaan tot de reeds van andere zijde verlangde wijziging van de bepaling der bankwet, volgens welke geen intrekking van bankbiljetten mag geschieden dan tot een maximum totaalsom van drie millioen dollars per maand. Tót weder-intrekking der aan de speciale belasting onderworpen biljetten zou ten allen tijde tot ieder bedrag gelegenheid mosten bestaan; anders zou de uitgifte de banken aan het gevaar van een aanzienlijk verlies bloot stellen.

Eindelijk stelde de Commissie ook de wijziging voor van de bepalingen welke tegenwoordig gelden voor het beheer der schatkist. Daaruit toch vloeit voort, dat, wanneer de staatsinkomsten ruim zijn, aan de geldmarkt de betaalmiddelen in groote bedragen worden onttrokken, terwijl wanneer het tegenovergestelde het geval is, de betaalmiddeleu overmatig naar de geldmarkt toevloeien. Hierin ware op de beste wijze verbetering te brengen geweest door de oprichting eener centrale circulatiebank, welke als rijkskassier optrad. Maar bij gebrek aan deze, moet aan den secretaris der schatkist de macht gegeven worden om alle inkomende gelden ì deposito te geven aan de Nationale banken, hetzij tegen onderpand van fondsen, hetzij tegen rentevergoeding; en alzoo zou dan gehandeld moeten worden voor ieder bedrag, in de schatkist aanwezig en daar niet vereischt voor deu dagelijkschen dienst.

Eu teu slotte gaf de Commissie ook den weusch te keuneu, dat toekomstige uitgiften van staatsobligatien niet meer mochten dieneu als grondslag voor daartegen door de Nationale banken uit te geven biljetten. Hierdoor zou dus aan de algemeene vermeerderiug van dit fiduciaire betaalmiddel een grens zijn gesteld. 
Zooals hierboven reeds gezegd is, zijn nu laatstelijk in de St. Louis-vergadering van de American Bankers Association deze voorstellen van de commissie der Kamer van Koophandel verwezen naar eeue speciale commissie der gennemde vereeniging om bij deze, in overleg met de commissie der Kamer van Koophandel, tot uitgangspunt eener te ontwerpen wetsvoordracht te dieneu.

Die commissie, de commissie der Kamer van Koophandel in haar midden vertegen woordigd zijude door de hecren Vanderlip en Conant, is van den $12^{\text {den }}$ tot den $16^{\text {den }}$ dezer maand te Washington vergaderd geweest onder het presidium van den heer A. Barton Hepburn, President van de Chase National Bank, die een der meest geachte bankdirecteuren van New-York is en iemand van groote autoriteit in de hank-wereld der Vereenigde Staten in het algemeen.

Als uitkomst harer werkzaamheid heeft zij een Memoraudum vast gesteld, inhoudende de groudslagen van een door haren voorzitter, in samenwerking met den heer James B. Forgan, President van de First National Bank van Chicago, en den heer Johu. L. Humilton van Hoopeston, Illinois, nader te redigeeren wetsontwerp. Het memorandum is geteekend door de vijftien ledeu der commissie en door de heeren Vanderlip en Conant, alsmede door den heer Charles N. Fowler, den voorzitter van het Bauking and Currency Committee van het Huis der Vertegenwoordigers, en zou, naar gemeld wordt, ook de goedkeuring hebben verkregen vau den Secretary of the Treasury en van den Comptroller of the Currency.

De gezegde grondslagen zijn de volgende:

Uitgifte vaukredietbiljetten (credit bauk notes).

Iedere Natiouale bauk, welke sedert teu minste een jaar werkzaam is geweest en een surplus (reserve) fonds heeft van ten minste twintig pCt. van haar kapitaal, zal gerechtigd zijn tot de uitgifte van kredietbiljetten op de volgende voorwaarden:

a. Tot een bedrag van $40 \mathrm{pC}$ t. van hare door stantsobligatien gewaarborgde biljetten-circulatie, tegen betaling eener belasting van $2 \frac{1}{2}$ pCt. per jaar over het gemiddeld uitstanude bedrag. Met dien verstande verder, dat wanneer te eeuiger tijd in het vervolg de totaalsom der uitstaande staatsobligatien in verhouding tot de 
totaalsom van het gezamenlijk kapitaal der Nationale banken eene vermindering zou hebben ondergaau, de hier genoemde verhoudiug tusschen de uit te geven kredictbiljetten en de door staatsobligatien gewaarborgde biljetten eene met die vermindering overeenkomende verhooging zal ondergaan.

l. Tot een bedrag van $12 \frac{1}{2} \mathrm{pCt}$. van haar kapitaal, tegen betaling vau eene belasting van $5 \mathrm{pCt}$. over het gemiddeld bedrag dezer suppletoire uitgifte.

De totaalsom dezer kredietbiljetten en der door staatsobligatien gewaarborgde biljetten zal het kapitaal der bank uiet mogen overschrijden.

Reserve.

Tegenover de uitgegeven kredietbiljetten moet een zelfde reserve (dekking iu wettig betaalmiddel) gehouden worden als thans door de wet is voorgeschreven tegenover de deposito's.

\section{Garantiefonds.}

De belastingen, waaraau de uitgifte van krediet-biljetten onderworpen wordt, zullen in goud gestort moeten worden in de Schatkist der Vereeuigde Staten en zullen eeu garantiefonds vormen ter inwisseling van de biljetten vau in gebreke gebleven bauken, alsmede tor vergoeding van de kosten der vervaardiging en der inwisseling van de biljetten. Ten einde dit garantiefonds van deu annvang af op een voldoend bedrag gebracht worde, zal iedere bank, bij de aanvrage van krediet-biljetten, 5 pCt. pCt. van het bedrag in goud à deposito storten in de schatkist. Die storting zal, voorzooveel niet aangesproken wegens de betalingen uit het garantiefonds eventueel te verrichten, een vordering blijven uitmakeu van de respectieve banken op de schatkist, en ze zal gerembourseerd worden naarmate het garantiefonds door de daarbij inkomende betalingen zoude stijgen boven $\breve{5}$ pCt. der uitstaande krediet-biljetten.

\section{Inwisseling.}

De Comptroller of the Currency zal een aantal plaatsen aanwijzen, verdeeld over het geheele land, waar de biljetten ter iuwisseling kunnen worden aangeboden. De dienst der inwisseling zal zoo geregeld worden, dat dagelijksche inwisseling verzekerd wordt. 
De bepaling der tegenwoordige wet, door welke de intrekking van door staatsobligatien gewaarborgde biljetten tot ee! bedrag van D. 3.000 .000 per maaul wordt beperkt, zal vervalleu.

Alle openbare gelden, met uitzondering alleen van zoodanig bedrag als voor den dagelijkschen dienst der schatkist vereischt wordt, zullen, onverschillig uit welken hoofde ingekomen, geregeld van dag tot dag à deposito gestort worden bij de Natiouale banken, zouder dat deze daarvoor bijzondere zekerheid te stellen hebbeu; in geen geval zal echter het deposito bij eenige bank meer mogen bedragen dan 50 pCt. vau haar kapitaal. Over deze deposito's zullen de bankeu aan de schatkist eene rente moeten vergoeden ì 2 pCt. per jaar.

Het memorandum der comnissie bevat, nevens deze groudslagen der te ontwerpen wet, eene korte toelichting, en deze wordt nog eenigszins angevuld door eene nota wariu de secretaris der American Bankers Assuciation van del arbeid der commissie verslag heeft gegeven.

De in deze stukken vervatte beschonwingen en redeneeringen sluiten zich echter geheel aan het rapport der commissie vau de kamer van koophaudel aau, en behueveu wij hier daarvan niet opuieuw te gewagen. Alleen dient de aaudacht gevestigd te worden op enkele afwijkingen der definitieve voorstelleu van die, welke door de commissie der Kamer van Koophandel werden geformuleerd, en op de motieven welke hiervoor zijn opgegeven.

De hoofdzak is, dat thans wordt voorgesteld aan de nitgifte der krediet-biljetten eene verplichte dekking in wettige betralmiddelen te verbinden, evenals is voorgeschreven voor de depositos.

Deze bepaling is onbetwijfelbaar een groote verbetering van het eerste voorstel. Ze is trouwens slechts de logische toepassing van het beginsel wanrvan de commissie der Kamer van Koophaudel is uitgegnan, tc weten dat tusschen het kredietbiljet en cen boekkrediet geeu essentienl verschil bestaat, illeen maar een van vorm. Noodweudig moesten dus ook aan de kriedietbiljetten dezelfde waarborgen verbonden worden als aau de boekkredieten. Voor de door staatsobligatien gewaarborgde biljetten is bij de herziening der bankwet vau 20 Juni 1874 die bepaling, welke in de oorspronkelijke bankwet wel bestond, ingetrokken. Men achtte die speciale dekking, waast het depot voor het volle bedrag 
der bankbiljetten in staatsobligatien, overbodig. Doch wat voor het bestaande bankbiljet met zijn tweeslachtig karakter geen vereischte geacht kon worden, is het voor het nieuwe biljet zeer zeker wel.

Een tweede punt van verschil tusschen de twee voorstellen is, dat thans wel het bedrag der uitgifte van krediet-biljetten, althaus in hoofdzaak, afhankelijk wordt gemaakt van het uitstaande bedrag der door staatsobligatien gewaarborgde biljetten. De nieuwe commissie was, evenals de commissie der Kamer van Koophandel, doordrongeu van de wenschelijkheid om te voorkomen, dat de uitgifte der nieuwe biljetten aanleiding kon geven tot het aan de markt brengen der thans als depot voor de oude biljetteu verbonden staatsobligatien. Maar zij achtte het brengen van een direct verband tusschen het bedrag der nieuwe biljetten en dat der oude, het beste middel om dit doel te bereiken. Ann de noodige voorziening voor het geval, dat het 'bedrag der oude biljetten eeue vermindering onderga door aflossing van staatsobligatien, is door haar in haar additioneel voorstel gedacht.

Eeu derde punt van verschil eindelijk, is de regeling der belasting. Door haar voorstel — dat danrbij veel eenvoudiger is, op zich zelf reeds een voordeel - acht de nieuwe commissie, dat op voldoende wijze gewaakt worlt tegen uitgifte der kredietbiljetten anders dan in het geval dat de rentestand zeer hong is. In verband met het verschil in de twee voorstellen ten aanzien der belastingheffing moet er ook op gelet worden, dat thans mede wordt voorgesteld het vormen eener speciale reserve t.egenover de kredietbiljetten, waardoor het netto-voordeel der uitgifte natuurlijk minder wordt.

In haar rapport vroeg de Kamer van Koophandel, bij de beoordeeling harer voorstellen niet over het hoofd te willen zien, dat zij zich op praktisch terrein moest bewegen. Geenzins, zeide zij, was het haar taak geweest eene regeling van geld- en bankwezen te ontwerpen, welke theoretisch het best te achten ware geweest ter vervanging der bestaande regeling, maar slechts om te overwegen welke verbeteringen in den bestanden toestand gewenscht en uitvoerbaar waren.

De opmerking is o. i. volkomen juist. Het geld-en bankwezen der Vereeuigde Staten kan gemakkelijk ten aanzien van schier 
ieder onderdeel annleiding geven tot gegronde kritriek. Het haudhaven na den oorlog van de staatsbiljetten onder de betaalmiddelen was een fout. Het annmuten van zilveren dollars als teekenmunt, gevolgd door het aankoopen van zilver tegeu uitgifte van zilver-certificaten, was dit niet minder. Theoretisch uujuist was de creatie van eeu baukbiljet tegen depot vau staatsobligatiën, van een fiduciair betaalmiddel dat dientengevolge volstrekt niet voldeed aan de eischen, welke aan een bankbiljet gesteld moeten worden, en toch ten deele dit wel was tegelijk dat het ook eeuigszins, schoon indirect, het karakter verkreeg vau papiereu-geld. Tal van bezwaren kunneu geopperd worden tegen de organisatie van het bankwezen op zich zelf, met zijn Nationale bauken, zijn staatsbankeu en zijn het bankbedrijf uitoefenende Trustcompagniën. Maar al die toestandeu ziju onder deu draug van verschillende omstandighedeu geworden, en een nieuwe regeling van geld-en bankwezen laat zich niet op eens improviseeren; het verkeer past zich steeds aan de bestaande regeling aan. En vooral niet in een land van zoo groote uitgebreidheid als de Verecuigde Staten, met ziju verschillende centrums vau uijverheid en handel en ziju verschillende plaatselijke behoeften en gewoonteu. Een laud buvendien dat wel een economische ééuheid vormt, maar war, wat wetgeving betreft, allerlei wrijving bestaat tusscheu de macht der onderscheidene staten en die der federale regeering.

Het gaat daarom dan ook niet aan de uu voorgestelde innovatie in de regeling vau het baukwezen der Vereenigde Stateu te beoordeelen op zuiver theoretische gronden, of te toetsen aau onze Europeesche toestanden.

Deed men dit, al dadelijk zou meu ook het uieuwe kredietbiljet, op zich zelf genomen, weder moeten afkeuren. Immers dit zal nu naar ziju aard een zuiver bankbiljet wezen, en toch komt de Staat weder tusschenbeide om voor de inwisseling te zorgen eu deze feitelijk te garandeereu. Maar hoe zou men voor de Vereenigde Stateu een bankbiljet verlangen, over het geheele land circuleerende en overal aangenomen wordende als ware het eigenlijk geld, wauneer er niet éénheid van bankbiljettencirculatie bestond, en in de plasts daarvan er duizenderlei verschillende biljetten in omloop waren, welke ieder voor zich slechts zouden moeteu drijven op het krediet der bank die ze uitgaf? 
Men neme dus deu stand van znken, zooals die is, tot uitgangspunt zijuer beoordeelingen. Eu handelt men alzoo, dan is het, naar wij meenen, aan geen twijfel onderhevig, dat de voorgestelde wijziging der bankwet een zeer degelijke en belangrijke verbetering in de bestaande organisatie zal te weeg brengen.

In den geldomloop der Vereenigde Staten zal alsdan een bestanddeel opgenumen wordeu dat daar tot nog toe volkomeu ontbroken heeft, een fiduciair betaalmiddel dat uit ziju aard bestemd is eeu afwisselend bedrag te vormen, dan eens kleiner en dau eens grooter, al naar gelaug de behoeften van het verkeer inkrimpiug der gezameulijke betaalmiddelen toelaten of uitzetting daarvan vorderen.

Het is de taak vau het fiduciaire betaalmiddel om bezuiniging mogelijk te maken in het gebruik der edele metalen in het verkeer; maar slechts ten deele en zeer gebrekkig vervult het die taak wanneer het onder de gezamenlijke betaalmiddelen een vaste grootheid uitmaakt. Juist voor zoover het kredietpapier, het reëele bankbillet, niet echter het papieren geld, het gebruik der edele metalen als betaalmiddel vervaugt, kuuneu deze, gemakkelijker en op minder kostbare wijze dan voor zooveel dit het geval uiet is, tijdelijke buitengewone uitzetting ondergaan. Of met audere woorden: waar als betaalmiddel gezamenlijk edele metalen en fiduciair papier, kredietpapier, dienst doen, daar kan tijdelijk aan het gebruik van het kredietmiddel eene buitengewone uitbreiding gegeven worden, veel gemakkelijker en met minder kosten dan dat tijdelijk de voorraad metalliek geld vermeerderd wordt.

Echter, zouder bezwaar voor de handhaving der gezamenlijke betaalmiddeleu op hunne goudwarde, en zonder gevaar ten aanzien der handhaving van het kredietpapier in den geldomloop, zal zulks slechts dau geschieden, wanneer dit een behoorlijke metallieke dekking heeft.

Terecht wordt dan ook in de voorgestelde wijziging van de bankwet der Vereenigde Staten de bepaling opgenomen van de verplichte minimum dekking der nieuwe kredietbiljetten.

Nochtaus, het wettelijke voorschrift, eeuer minimum dekking en de nakoming daarvan zijn slechts het begin vau wat vereischt wordt, om van het fiduciaire betaalmiddel al het mogelijke voordeel te trekken en het volledig aan zijn doel te doen be- 
antwoorden. Alleen dan zal dit het geval zijn, wanneer er voor gewakt wordt dat in tijden van betrekkelijke geldruimte, van slapheid van kredietvraag, de feitelijke dekking de wettelijke ruim overschrijdt. De in de Ver. Staten gebruikte term voor de metallieke dekking der bank-obligo's t. w. "reserve" geeft op volkomen juiste wijze an wat het doel is dier dekking. Ze is een reserve, een middel dat men achter houdt, als waarborg voor de zekerheid van de nakoming zijner verplichtingen, in dit geval van de voortdurende inwisselbaarheid van het kredietpapier. En terecht is iu de meeste landen bij de wettelijke regeling van het bankwezen voor die reserve een verplicht minimum voorgeschreveu. Doch de reëele bedrijfs-reserve, de reserve welke bestemd is om haar dieust te doen in de perioden van leveudige kredietvrang of onder buitengewone omstandigheden, is dat deel der reserve hetwelk de banken onder gewone omstandighedeu houdeu boven het wettelijk minimum. Alleen in haar "surplus-reserve", in het "beschikbaar metaal-saldo" vindt eene bank het middel tot tijdelijke uiizetting harer ongedekte circulatie boven het normaal bedrag daarvan.

Het waken voor het bezit eener zoodanige surplus-reserve is echter uiet een $\mathrm{k}$ westie van wettelijke bank-regeling, maar van bank-politiek. Eu het laat zich niet tegenspreken, dat dit een zeer zwakke zijde is in het bankwezen der Vereenigde Staten. Er bestaat oumiskenbaar bij de banken aldaar een neiging om a anhoudend hare reserves te lateu afloopen tot de uiterste grens, welke bij de wet is angewezen. Komt hierin geen verbetering, dau zal ook door de nu ontworpen herziening der bankwet slechts half werk verricht worden.

Terecht wees de commissie der Kamer vau Kuophandel in haar lapport op het groote voordeel, dat er in gelegen zal ziju wanneer de stedelijke banken niet meer in het seizoen der oogstbeweging een bedrag van mogelijk wel 100 of zelfs 200 millioen dollars in wet.tige betaalmiddelen af to geven zullen hebben, en daarentegen dat bedrag zullen kunnen fouruecren in haar eigen biljetten. Immers, voegde de commissie hieraan toe, de banken zullen alsdan niet meer, zooals tegenwoordig het geval is, die uitbetaling gepaard moeteu laten gaan met een opzegging der door haar op den grondslag van dit bedrag verleende kredieten. Volkomen juist; doch de uitzending van een bedrag van, stellen 
wij, honderd millioen dollars bankbilletten zal toch altijd verplichten daartegen een reserve te houden van vijfentwintig millioen aan wettige betaalmiddelen. Indien dan dit bedrag niet als surplus-reserve in voorraad gehouden is, maar in het voorjaaren zomerseizoen gebruikt is om daarvoor b. v. aal de NewYorker fondseumarkt kredieten te verleenen, zullen toch - zij het dau ook in mindere mate - de tegenwoordige moeilijkheden zich nog altijd blijven voordoen.

Een goede bankpolitiek is het zekerst te verwachten vau, het gemakkelijkst te voeren door, éne centrale circulatiebank. Onbetwijfelbaar zouden echter de groote New-Yorker banken, welker invloed op de geldmarkt in de Vereenigde Staten van overwegende beteekenis is, veel kunueu doen om in dit opzicht ann het gemis der centrale circulatiebauk te gemoet te komen. Hare organisatie in het Clearing House geeft haar daartoe ook reeds het middel aan de hand. Daartoe zou het evenwel noodig wezen, dat de directeureu der banken begrepen vau hunne positie en vall den invloed op den algemeenen gaug vall zaken, welken zij an deze dauken, uitsluitend gebruik te moeten maken in het belaug der geldmarkt in het algemeen, eu niet ter bevordering van andere belangen. En bekend is 't dat, zeer' ougelukkig, de tegenovergestelde gedragslijn niet zelden door eenige van juist de meest invloedrijke bank-directeuren scheen gevolgd te worden. Ook iu den loop van dit jaar zag men weder herhaaldelijk de koers van call-money op 2 en zelfs $l_{2}^{1}$ pCt. dalen, terwijl toch de surplus-reserve der New-Yorker Clearinghouse bauken anhoudend slechts van zeer weinig beteekenis was. En uu leest men wel in het rapport van de commissie der Kamer van Koophandel, dat eeu zeer gedrukte rentestaud in voorjaar en zomer onvermijdelijk is wegeus de alsdau plaats vindende toestrooming naar de stedelijke bankeu van betaalmiddelen, en omdat zij die gelden niet ongebruikt kunnen laten liggen wijl zij over de depositos reute vergoeden. $\left.{ }^{1}\right)$ Maar wie noodzaakt deze banken die depositos aau te nemen tegen zoo hooge rente, dat zij darrvoor weder platsing moeten zoeken iu ruimere verhouding dan op zichzelf weuschelijk ware? Zij worden,' zegt men, iudien al niet bij-oogmerken in het spel

1) Zie hiervon h. 86 (i3. 
zijn, daartoe gedwongen door onderlinge concurrentie. Maar dit is juist een kwaad, dat voorkomen kon worden door samenwerking ter bevordering van goede bankpolitiek.

$\mathrm{Er}$ is, gelukkig, in die richting af en toe in de laatste jaren wel eenige beweging op te merken geweest, en het jongste overleg ter zake van de herziening der bankwet getuigt ook weder daarvan. Maar de beweging kon sterker zijn en moest dit wezen.

Teekenen wij ten slotte nog aan, dat het geregeld terugbrengen an de geldmarkt van de zich in de schatkist ophoopende betaalmiddelen een zeer goede, trouwens sedert lang van alle zijden verlangde, maatregel zal zijn. Niet zonder bedenking is het echter, dat de banken over deze depositos steeds $2 \mathrm{pCt}$. rente te vergoedeu zulleu hebben. Het moet niet vau den goeden wil en het goed inzicht van den Secretaris der Schatkist afhangen of deze gelden aan de markt onthouden zullen blijven of niet. Maar het is weder eeu $k$ westie van bankpolitiek of, op een gegeven oogenblik, ze gebruikt moeten worden ter vermeerdering van het opereerend kapitaal der banken, dan wel ter versterking harer surplus-reserve. Welnu, door de voor die depositos bedongen wordende vaste rentevergoeding worden de banken in hare vrijheid te dezen opzichte belemmerd. Eeu bank moet altijd de vrijheid aau zich houden, de rentekoers voor hare depositos te bepalen.

November 1906 . G. M. Borssevain.

\section{Naschrift, 7 Degember.}

Sedert de voorgaande bladzijden geschreven werden, ziju de eerste berichten ontvangen betreftende den inhoud van de Boodschap vau den President en van het Jaarverslag van den Secretaris der Schatkist.

Ze bevestigen hetgeen verwacht werd, n. l. dat beiden zouden spreken ten gunste eener uitgifte vau krediet-biljetten door de Nationale baukeu. Beideu dringeu daarbij er uitdrukkelijk opaan, dat die uitgifte zou moeten geschieden op zoodanige voorwarden als waardoor verzekerd worde, dat deze biljetten slechts eene tijdelijke uitzetting van de fiduciaire circulatie zouden veroor- 
zaken. De President maakt verder het uitdrukkelijke voorbehoud, dat bij de regeling der zaak er gelet worde op de noodzakelijkheid om alles te vermijden waardoor de handhaving der tegenwoordige beurswaarde van de 2 pCts staatsobligatien in gevaar wierd gebracht.

De opheffing der bepaling, volgens welke de gellen door de Schatkist outvangen voor inkomende rechten niet ter beschikking zijn van den Secretaris der Schatkist om a deposito te worden uitgezet, wordt ook door den President aanbevolen. Maar, naar het schijnt, zou de Secretaris der Schatkist er tegen zijn, dat alle bij de schatkist inkomende gelden onverwijld bij de banken werdeu overgebracht. Hij schijnt het meer in het belang der geldmakt te achten, dat hemzelf de gelegenheid worde gegeven het tijdelijk na te laten, wanneer hij het wenschelijk oordeelde daardoor een extra-reserve voor de geldmarkt te vormen. Althans, tenzij door eene doeltreffende regeling te verzekeren ware, dat de banken hare reserves naar omstandigheden opvoeren boven het wettelijke minimum, zegge: een surplus-reserve vormen.

In verband met hetgeen schr. zelf over dit piut heeft geschreven, is het schier overbodig op te merken, dat de beschouwingen van den Secretaris der Schatkist over het ouderwerp alle aandacht zulles verdienen. Maar ter richtige beoordeeling, zal het noodig wezen zijn betoog in extenso te kennen.

G. M. B. 